\title{
Regulating of Ripening and Maintaining the Quality of Banana Fruits Treated with 1- Mcp Exogenous Ethylene and Storage Temperature
}

Naglaa M.Yassin ${ }^{1}$ and Enas A.Tayel ${ }^{2}$

\begin{abstract}
Banana fruits Musa spp. were exposed to 1-MCP (1methylcyclo propen) $(0.01,0.5,1 \mathrm{ppm})$ treatments at $20^{\circ} \mathrm{C}$ for $24 \mathrm{~h}$ and stored at $13^{\circ} \mathrm{C}$ and other banana fruits were exposed to 1-MCP $(0.01,0.5,1 \mathrm{ppm})$ treatments at $20^{\circ} \mathrm{C}$ for $24 \mathrm{~h}$ with ethylene application and then stored at $20^{\circ} \mathrm{C}$. Color, firmness, acidity, total soluble sugars (SSC) were determined. Fruits which treated with $\mathrm{MCP}(0.01,0.5,1$ ppm) at $13^{\circ} \mathrm{C}$ and at $20^{\circ} \mathrm{C}$ and those treated with MCP ethylene application had higher significant firmness.
\end{abstract}

In the first season, the total soluble solids (SSC) showed in the fruit pulp were significant differences between fruits treated which $\mathrm{MCP}(0.01 \mathrm{ppm})$ at $13^{\circ} \mathrm{C}$ and those treated with $\mathrm{MCP}(0.5 \mathrm{ppm})$ and ethylene and stored at $20^{\circ} \mathrm{C}$ and other treatments.

MCP treated fruits $(0.01,1 \mathrm{ppm})$ and stored at $13^{\circ} \mathrm{C}$ had lower acidity in comparison with the other treatments. Moreover, fruits which treated with MCP and stored at $13^{\circ} \mathrm{C}$ and those treated with MCP and ethylene and stored at $20^{\circ} \mathrm{C}$ had higher total sugars as compared with the untreated fruits (control). Concerning reducing sugars, the fruits that treated with $\mathrm{MCP}(0.01 \mathrm{ppm})$ and stored at $13^{\circ} \mathrm{C}$ or $20^{\circ} \mathrm{C}$ in both seasons had significantly higher values, in the second season, the fruits which treated MCP $(0.01,0.5,1 \mathrm{ppm})$ and stored at $13^{\circ} \mathrm{C}$ or $20^{\circ} \mathrm{C}$ had significantly higher values.

In the meantime, the fruits which treated with MCP (1 ppm) and stored at $13^{\circ} \mathrm{C}$ and those treated with MCP $(0.01,0.5 \mathrm{ppm})$ and stored at $20^{\circ} \mathrm{C}$, showed higher significant values of non-reducing sugars. Color index was obvious in the fruits which treated with MCP and ethylene at $20^{\circ} \mathrm{C}$ after 40 days of storage but fruits treated with MCP and stored at $13^{\circ} \mathrm{C}$ changed to yellowish after 50 days of storage and control fruits were changed after 20 days of storage.

In both seasons, firmness and acidity no well decreased by the advancing of storage and non-reducing sugars decreased after 30 days of storage. While, weight loss, SSC, total sugars, reducing sugars, color were increased by the end of the storage at $13^{\circ} \mathrm{C}$ or $20^{\circ} \mathrm{C}$.

\section{INTRODUCTION}

Banana (Musa spp.) is one of the major fruits in Egypt, has now moved from backyard to commercial production, with an annual production of 9.000 tones for the local market. Banana being a delicate and highly perishable fruit, the local production is subjected to serious postharvest losses, mainly due to poor handling and storage practices and postharvest diseases (Ramma et al., 1998). Consumers demand high quality of food they consume such demands include taste, appearance or shape of banana. As it is known, food safety has become a very significant issue, particularly after the food scares in Europe. Consumers want to be informed about the food they are consuming through appropriate labeling and tracking and traceability schemes. Quality standards may vary in the different markets.

The ability of 1- methyl cyclopropene (1-MCP) to delay ripening of mature-green, pre-climacteric bananas has been widely demonstrated (Sisler and Serek, 1997; Golding et al., 1998; Joyce et al., 1999) as well as the time, concentration and temperature dependence of this response (Yueming et al., 1999, Macnish et al., 2000). However, the reported efficacy of 1-MCP in these studies was quite variable. Hypothesized that there was significant interaction between the effectiveness of 1MCP and the maturity of bananas, they found that 500 $\mathrm{ml}$ of $1-\mathrm{MCP}$ at $20.8^{\circ} \mathrm{C}$ for $24 \mathrm{~h}$ was more effective in delaying ripening as maturity progressed from 71 to 173 days after bunch emergence, although the absolute time for bananas to ripen decreased from 40 to 28 days respectively, at $20.8^{\circ} \mathrm{C}$ in a continuous air flow containing $0.1 \mathrm{ml}$ ethylene.

Commercially, once bananas are induced to ripen with ethylene their marketing life is only about 3,5 days depending on ethylene treatment conditions and holding temperature after treatment.

A method to slow down the ethylene induced ripening process has economical significance for distribution centers and super markets.

The purpose of this study was to evaluate the efficacy of 1- MCP on ripening associated with changes of bananas at selected stages of ripeness after the commercial application of ethylene.

\section{MATERIALS AND METHODS}

The present study was carried out during 2007 and 2008 seasons on bananas fruits (Musa spp).

The fruits were harvested from plants grown in two private orchards, banana plant is not a tree where is the second orchard of Hegazi farm on the desert road near Cairo, at mature green stage. Fruits were free of obvious mechanical damage and defects and approximately

1Hort. Res. Station, Sabahia, Alex., Hort. Res. Ins., A.R.C. Giza, Egypt.

${ }^{2}$ Mamoura Bot. Garden, Alex., Hort. Res. Instit. Agric. Res. Center, Egypt.

Received August 14, 2011, Accepted September20, 2011 
homogenous in size. Fruits were brought as soon as possible after harvest to the Postharvest Laboratory of Pomology Department, Faculty of Agriculture, Alexandria University. Sorted fruits were washed with tap water, then air dried with the aid of an electric fan. Fruits were divided into two groups (lots), fruits of the first one were treated with MCP (1-Methylcyclo propen) $(0.01,0.5,1 \mathrm{ppm})$ and control treatment. Fruits with second one were treated with ethylene after 20 days of the previous treatments (with MCP) and control treatment. Eight treatments were used as follows:

- Fruits treated with MCP $(0.01 \mathrm{ppm})$ for $24 \mathrm{~h}$ at $20^{\circ} \mathrm{C}$ injection in jar with MCP $(60 \mathrm{ml}+\mathrm{MCP})$ and transfered to $13^{\circ} \mathrm{C}\left(\mathrm{T}_{1}\right)$ for the end and closed the jar with wax.

- Fruits treated with $\mathrm{MCP}(0.5 \mathrm{ppm})$ for $24 \mathrm{~h}$ at $20^{\circ} \mathrm{C}$ and transfered to $13^{\circ} \mathrm{C}\left(\mathrm{T}_{2}\right)$.

- Fruits treated with MCP (1 ppm) for $24 \mathrm{~h}$ at $20^{\circ} \mathrm{C}$ and stored at $13^{\circ} \mathrm{C}\left(\mathrm{T}_{3}\right)$.

- Fruits stored at $13^{\circ} \mathrm{C}\left(\mathrm{T}_{4}\right)$ are those fruits treated or untreated.

- Fruits treated with MCP $(0.01 \mathrm{ppm})$ for $24 \mathrm{~h}$ at $20^{\circ} \mathrm{C}$ and treated with ethylene (ethyle $40 \mathrm{ml}+10$ liter water for 5 minutes) after 20 days of MCP treatment and then stored at $20^{\circ} \mathrm{C}$ until the end $\left(\mathrm{T}_{5}\right)$.

- Fruits treated with MCP $(0.5 \mathrm{ppm})$ for $24 \mathrm{~h}$ at $20^{\circ} \mathrm{C}$ and treated with ethylene (ethyle $40 \mathrm{ml}+10$ liter water for 5 minutes) after 20 days of MCP treatment and then stored at $20^{\circ} \mathrm{C}$ until the end $\left(\mathrm{T}_{6}\right)$.

- Fruits treated with MCP (1 PPM) for $24 \mathrm{~h}$ at $20^{\circ} \mathrm{C}$ and treated with ethylene (ethyle $40 \mathrm{ml}+10$ liter water for 5 minutes) after 20 days of MCP treatment and then stored at $20^{\circ} \mathrm{C}$ until the end $\left(\mathrm{T}_{7}\right)$.

- Fruits untreated stored at $20^{\circ} \mathrm{C}$ (control $\mathrm{T}_{8}$ ).

Physiochemical changes of the fruits associated with storage temperature were determined as follow:

\section{(1) Physical characteristics:}

\section{(1) Fruits weight loss:}

Five fruits were labeled in each $13^{\circ} \mathrm{C}$ treatments and the initial weight of each labeled fruit was recorded.

The percentage of weight loss for each fruit was calculated in relation to its initial weight, and the average weight loss was calculated for each treatment according to the following equation:

Weight loss $(\%)=\frac{\text { Initial weight }- \text { Sample weight }}{\text { Initial weight }} \times 100$

\section{2- Fruits firmness:}

Flesh firmness was determined in for given sample by peeling the two opposite sides of the fruit and the firmness of each side was measured using the Effegi firmness tester with an eight mm plunger (Effegi, 48011 Alfonsine, Italy).

The average flesh firmness of each sample of fruits was estimated. Fruit firmness was expressed as pound/ square inch.

\section{(2) Biochemical properties:}

\section{1- Soluble solids content (SSC):}

The soluble solids content of fruit juice was measured using a hand refractometer, according to Chen and Mellenthin (1981). The soluble solids content was expressed as percent.

\section{2- Total carbohydrates:}

The sugars were extracted from five grams of well mixed flesh of fruit samples. The extraction was carried out by using distilled water according to Loomis and Shull (1937). The reducing sugars as well as the total sugars of the extract were determined, respectively, before and after hydrolysis with hydrochloric acid by the Nelson arseno molybdate colorimetric method as described by Malik and Singh (1980). The non-reducing sugars were calculated using the difference between the total and the reducing sugars. Sugars content was expressed as grams per $100 \mathrm{gm}$ fresh weight of fruit flesh.

The starch was determined in $0.1 \mathrm{gm}$ of the dry residue after extraction, by hydrolysis with concentrated hydrochloric acid for 3 hours and the reducing power of the hydrolysate was estimated in terms of glucose, according to A.O.A.C. (1990). Starch content was expressed as grams per 100gm dry weight of fruit flesh.

\section{3- The titratable acidity:}

Five $\mathrm{ml}$ samples of the fruit juice were used to determine the titratable acidity. For the titration, $0.1 \mathrm{~N}$ sodium hydroxide was used in the presence of phenolphthalein as an indicator, according to Chen and Mellenthin (1981). The titratable acidity was expressed as grams of malic acid per $100 \mathrm{ml}$ of banana juice.

Randomized complete block design with three replicates was used, and all the obtained data were statistically analyzed according to Gomez and Gomez (1983).

\section{RESULTS AND DISCUSSION}

\section{(1) Physical characteristics:-}

\section{1- Firmness:}

Data obtained regarding fruit firmness for seasons of 2007 and 2008 are presented in Table (2). It was shown that, in the two seasons, there were no significant difference among all treatments concerning such a trait compared with control fruits except those treated with 


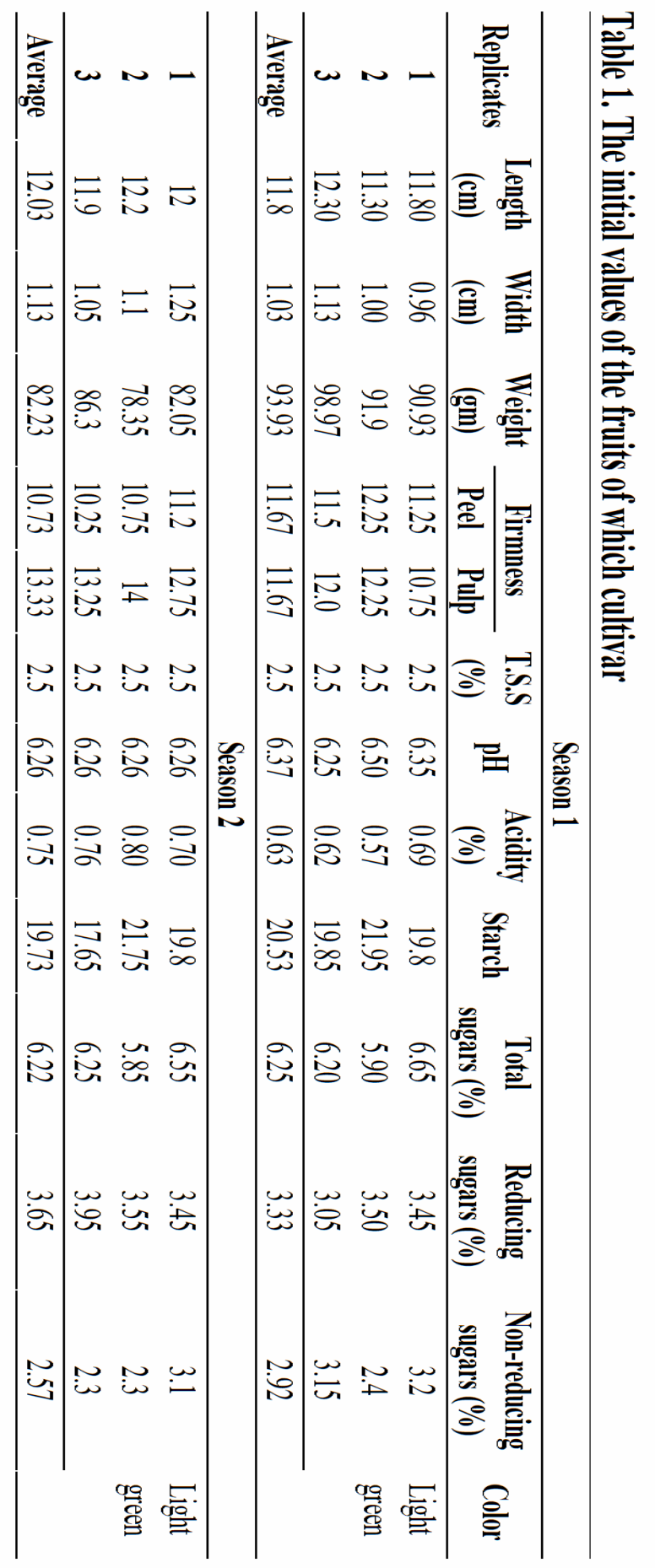


Table 2. Effect of 1-MCP and ethylene treatments and storage temperature on fruits firmness during 2007 and 2008 seasons

\begin{tabular}{|c|c|c|c|c|c|c|c|}
\hline \multicolumn{8}{|c|}{ Storage period (days) } \\
\hline $\begin{array}{c}\text { Period } \\
\text { Treat. }\end{array}$ & 0.0 & 10 & 20 & 30 & 40 & 50 & Average \\
\hline & \multicolumn{7}{|c|}{ Season 1} \\
\hline 1 & $11.66^{\mathrm{ab}}$ & $11.96^{\mathrm{ab}}$ & $12.19^{\mathrm{ab}}$ & $12.69^{\mathrm{a}}$ & $11.08^{\mathrm{ab}}$ & $2.0^{\mathrm{d}}$ & $10.26^{\mathrm{a}}$ \\
\hline 2 & $11.66^{\mathrm{ab}}$ & $12.85^{\mathrm{a}}$ & $12.31^{\mathrm{ab}}$ & $11.11^{\mathrm{ab}}$ & $7.89^{c}$ & $3.66^{\mathrm{d}}$ & $9.91^{\mathrm{a}}$ \\
\hline 3 & $11.66^{\mathrm{ab}}$ & $12.57^{\mathrm{a}}$ & $12.21^{\mathrm{ab}}$ & $11.42^{a b}$ & $10.71^{\mathrm{ab}}$ & $2.06^{\mathrm{d}}$ & $10.10^{\mathrm{a}}$ \\
\hline 4 & $11.66^{\mathrm{ab}}$ & $12.82^{\mathrm{a}}$ & $12.26^{\mathrm{ab}}$ & $1.46^{\mathrm{d}}$ & - & - & $9.55^{\mathrm{ab}}$ \\
\hline 5 & $11.66^{\mathrm{ab}}$ & $12.16^{\mathrm{ab}}$ & $10.75^{\mathrm{ab}}$ & $9.66^{b}$ & $1.36^{\mathrm{d}}$ & - & $9.11^{\mathrm{b}}$ \\
\hline 6 & $11.66^{\mathrm{ab}}$ & $11.05^{\mathrm{ab}}$ & $10.51^{\mathrm{ab}}$ & $7.48^{c}$ & $1.73^{\mathrm{d}}$ & - & $8.48^{b}$ \\
\hline 7 & $11.66^{\mathrm{ab}}$ & $12.01^{\mathrm{ab}}$ & $11.68^{\mathrm{ab}}$ & $6.76^{\mathrm{c}}$ & $1.33^{\mathrm{d}}$ & - & $8.68^{b}$ \\
\hline 8 & $11.66^{\mathrm{ab}}$ & $12.31^{\mathrm{ab}}$ & $3.06^{\mathrm{d}}$ & - & - & - & $9.01^{\mathrm{b}}$ \\
\hline \multirow[t]{2}{*}{ Average } & $11.66^{\mathrm{a}}$ & $12.21^{\mathrm{a}}$ & $10.62^{\mathrm{a}}$ & $8.65^{\mathrm{ab}}$ & $5.68^{b}$ & $2.57^{b}$ & \\
\hline & \multicolumn{7}{|c|}{ Season 2} \\
\hline 1 & $10.75^{b c}$ & $11.38^{\mathrm{ab}}$ & $12.69^{\mathrm{ab}}$ & $12.61^{\mathrm{ab}}$ & $8.62^{\mathrm{cd}}$ & $2.00^{\mathrm{fg}}$ & $9.67^{\mathrm{ab}}$ \\
\hline 2 & $10.75^{b c}$ & $11.83^{\mathrm{ab}}$ & $11.98^{\mathrm{ab}}$ & $11.55^{\mathrm{ab}}$ & $9.46^{\mathrm{c}}$ & $5.26^{\mathrm{e}}$ & $10.13^{\mathrm{a}}$ \\
\hline 3 & $10.75^{b c}$ & $12.59^{a b}$ & $12.95^{\mathrm{a}}$ & $12.20^{\mathrm{ab}}$ & $11.66^{a b}$ & $2.66^{\mathrm{fg}}$ & $10.46^{\mathrm{a}}$ \\
\hline 4 & $10.75^{b c}$ & $11.58^{\mathrm{ab}}$ & $11.51^{\mathrm{ab}}$ & $1.53^{\mathrm{fg}}$ & - & - & $8.84^{b}$ \\
\hline 5 & $10.75^{b c}$ & $11.73^{\mathrm{ab}}$ & $10.15^{b c}$ & $7.92^{\mathrm{cd}}$ & $1.73^{\mathrm{fg}}$ & - & $8.45^{b}$ \\
\hline 6 & $10.75^{b c}$ & $11.56^{\mathrm{ab}}$ & $11.22^{b}$ & $7.72^{\mathrm{d}}$ & $1.33^{\mathrm{g}}$ & - & $8.51^{\mathrm{b}}$ \\
\hline 7 & $10.75^{b c}$ & $12.81^{\mathrm{ab}}$ & $10.93^{b c}$ & $7.41^{\mathrm{d}}$ & $1.33^{\mathrm{g}}$ & - & $8.64^{b}$ \\
\hline 8 & $10.75^{b c}$ & $11.24^{\mathrm{ab}}$ & $3.17^{\mathrm{f}}$ & - & - & - & $8.38^{b}$ \\
\hline \multirow[t]{4}{*}{ Average } & $10.75^{a}$ & $11.84^{\mathrm{a}}$ & $10.57^{\mathrm{a}}$ & $8.70^{\mathrm{ab}}$ & $5.68^{b}$ & $3.30^{\mathrm{b}}$ & \\
\hline & \multicolumn{3}{|c|}{ L.S.D 0.05} & A & & & \\
\hline & \multicolumn{3}{|c|}{ Season 1} & 2.18 & & & \\
\hline & \multicolumn{3}{|c|}{ Season 2} & 1.97 & & & \\
\hline
\end{tabular}

$\mathrm{MCP}$ and stored at $13^{\circ} \mathrm{C}$ which higher firmness as compared with those treated with MCP and ethylene. These results are in agreement with Boonyaritthon and Kanlayanarat (2009) and Clara Pelaya et al. (2003).

Fruit firmness of all treated fruit decreased with the duration in this really cold storage at $13^{\circ} \mathrm{C}$ and $20^{\circ} \mathrm{C}$ in the two seasons. The results agree with those of (Rippon and Trochoulias, 2007).

The decrease in the rate of firmness at the absence of ethylene may be due to inhibition of the synthesis of cell wall hydrolytic enzymes such as polygalactoranase and $a-b-$ galactosidase, maintaining membrane stability and reducing the solubility of palyuranide.

\section{2- Weight loss \%:}

The data illustrated in Table (3) showed weight loss percentages values. It is clear that weight loss \% was gradually increased as an average for all treatments, by increasing the storage period, the results of as indicated by (Yassin and Tayel, 2010) on cactus pear.
The differences among all storage periods were significant in both years of study. The highest percentage of weight loss, in both seasons were found in fruits that treated with $\mathrm{MCP}(0.01,0.5,1 \mathrm{ppm})$ and ethylene application and stored at $20^{\circ} \mathrm{C}$ as compared with those treated with $\mathrm{MCP}(0.01,0.5,1 \mathrm{ppm})$ only and stored at $13^{\circ} \mathrm{C}$ in both seasons.

Similar, the obtained results were found by Domingo Martinez Romero et al. (2003) on plum which indicated that MCP treated fruits showed lower weight loss. On the other hand, Salvador et al. (2003) working on Santo Rosa plums reported that MCP did not affect on weight loss of fruits. Also, Calvo (2002) they mentioned that there were no significant effects of 1MCP treatment on weight loss of pear fruits. 
Table 3. Effect of 1-MCP and ethylene treatments and storage temperature on weight loss (\%) of banana fruits during 2007 and 2008 seasons

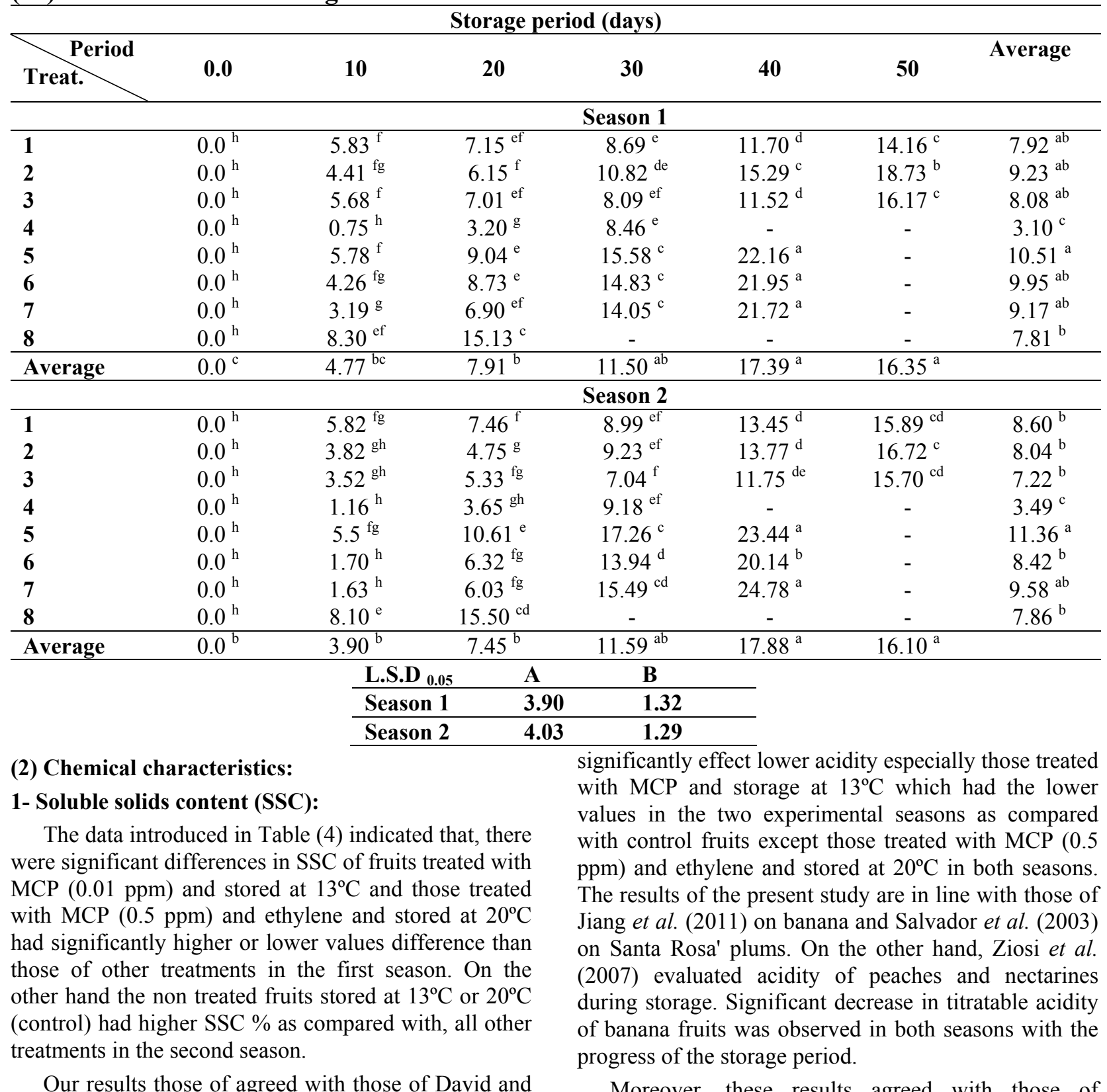

Our results those of agreed with those of David and Whyte (2009) who found that SSC in the fruit pulp as the storage period extends could be due to degradation of the complex insoluble compounds like sugars that are the major component of SSC content in the fruits such an interpretation came on line with that of Chen and Mellenthin (1981).

\section{2-Titratable acidity (\%):}

In the two experimental seasons, data of citric acid content of the experimental fruits are presented in Table (5) showed that the fruits treated with MCP had
Narayana et al. (2006) on banana and Dnake (1998) and Argenta and Mondardo (1994) who reported that acidity decreased during storage on Gala apple.

\section{3- Total sugars content:}

The data tabulated in Table (6) indicated that, total sugars content increased significantly on fruits in the pulp which treated with MCP and stored at $13^{\circ} \mathrm{C}$ and those treated with MCP and ethylene and stored at $20^{\circ} \mathrm{C}$ as compared with untreated fruits in the both seasons. 
On the other hand, Jiang et al. (2011) and Salvador et al. (2006) reported that 1-MCP did not affect the sugar content.

In this respect, Narayana et al. (2006) found that total sugars increased gradually throughout the storage period of banana CV. Kar Puravalli. The increment in the total sugar content could be due to the breaking down of the starch to simple sugars. This conclusion is in line with that of David and Whyte (2009) who stated that increasing sweetness of ripening fruit was due to breaking down starch to produce simple sugars.

\section{4- Reducing and non reducing sugars:}

The data concerning in Tables (7 and 8) showed the reducing and non reducing sugars values of the experimental treatments.

In both seasons, reducing sugars in fruits treated with MCP $(0.01 \mathrm{ppm})$ were significantly higher different than those of control fruits and those treated with MCP (0.01 ppm) and ethylene application differed than the control fruits in both seasons, the fruits those treated with $\operatorname{MCP}(0.01,0.5,1 \mathrm{ppm})$ and ethylene application had significantly higher reducing sugars as compared with control fruits in the second season. Generally, reducing sugars increased significantly during storage periods of banana fruits in both seasons and such findings a greed with those of Narayana et al. (2006).

Non reducing sugars in the fruits treated with MCP (1 ppm) and MCP $(0.01,0.5 \mathrm{ppm})$ with ethylene application, in both seasons. These results agree with those of Jiang et al. (2011). Non reducing sugars decreased significantly for 30 days and increased significantly after 30 days in both seasons. These changes are related to starch synthesis degration, depending on starch and sugar content in the fruits at harvest, Lopez et al. (2003).

\section{5- Color index of fruits:}

The color is one of the main attributes of banana fruits which can determine the consumer acceptability and serve as an indicative of the harvest point of some fruits, (Silva et al., 2009) on cactus pear. The visual observation of the external of color fruits in this work showed that skin color changed with the progress of the storage period and was faster at $20^{\circ} \mathrm{C}$ (Table 9).

Table 4. Effect of 1-MCP and ethylene treatments and storage temperature on soluble solids content (SSC \%) of banana fruits during 2007 and 2008 seasons Storage period (days)

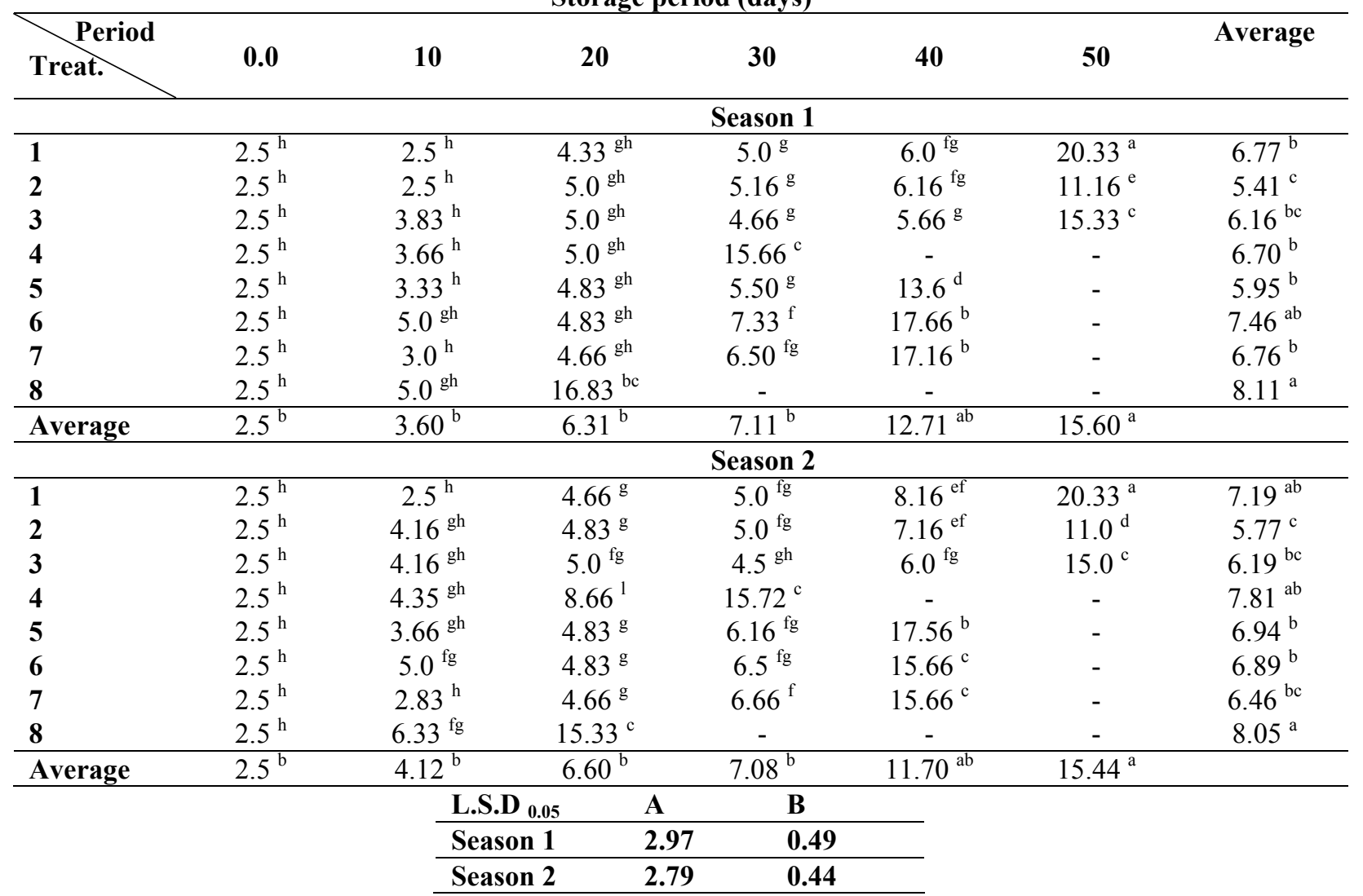


Table 5. Effect of 1-MCP and ethylene treatments and storage temperature on titratable acidity (\%) of banana fruits during 2007 and 2008 seasons

\begin{tabular}{|c|c|c|c|c|c|c|c|}
\hline \multicolumn{8}{|c|}{ Storage period (days) } \\
\hline $\begin{array}{l}\text { Period } \\
\text { Treat. }\end{array}$ & 0.0 & 10 & 20 & 30 & 40 & 50 & Average \\
\hline & \multicolumn{7}{|c|}{ Season 1} \\
\hline 1 & $0.629^{b c}$ & $0.612^{c}$ & $0.513^{\mathrm{cd}}$ & $0.424^{\mathrm{de}}$ & $0.549^{\mathrm{cd}}$ & $0.370^{\mathrm{e}}$ & $0.516^{\mathrm{bc}}$ \\
\hline 2 & $0.629^{b c}$ & $0.718^{b}$ & $0.520^{\mathrm{cd}}$ & $0.396^{\mathrm{e}}$ & $0.541^{\mathrm{cd}}$ & $0.43^{\mathrm{de}}$ & $0.539^{b c}$ \\
\hline 3 & $0.629^{b c}$ & $0.677^{b c}$ & $0.438^{\mathrm{de}}$ & $0.317^{\mathrm{e}}$ & $0.432^{\mathrm{de}}$ & $0.413^{\text {de }}$ & $0.484^{\mathrm{c}}$ \\
\hline 4 & $0.629^{b c}$ & $0.867^{\mathrm{a}}$ & $0.656^{b}$ & $0.396^{\mathrm{e}}$ & - & - & $0.637^{\mathrm{a}}$ \\
\hline 5 & $0.629^{b c}$ & $0.727^{b}$ & $0.504^{\mathrm{d}}$ & $0.449^{\mathrm{de}}$ & $0.46^{\mathrm{de}}$ & - & $0.553^{b}$ \\
\hline 6 & $0.629^{b c}$ & $0.792^{\mathrm{ab}}$ & $0.610^{\mathrm{cd}}$ & $0.424^{\text {de }}$ & $0.455^{\mathrm{de}}$ & - & $0.582^{\mathrm{ab}}$ \\
\hline 7 & $0.629^{b c}$ & $0.337^{\mathrm{e}}$ & $0.628^{b c}$ & $0.404^{\mathrm{de}}$ & $0.469^{\text {de }}$ & - & $0.493^{c}$ \\
\hline 8 & $0.629^{b c}$ & $0.651^{b c}$ & $0.423^{\mathrm{de}}$ & - & - & - & $0.567^{b}$ \\
\hline \multirow[t]{2}{*}{ Average } & $0.629^{\mathrm{ab}}$ & $0.672^{\mathrm{a}}$ & $0.436^{b}$ & $0.401^{\mathrm{c}}$ & $0.484^{\mathrm{bc}}$ & $0.404^{\mathrm{c}}$ & \\
\hline & \multicolumn{7}{|c|}{ Season 2} \\
\hline 1 & $0.753^{a b}$ & $0.492^{\mathrm{cd}}$ & $0.619^{b c}$ & $0.437^{\mathrm{d}}$ & $0.594^{b}$ & $0.370^{\text {de }}$ & $0.544^{b c}$ \\
\hline 2 & $0.753^{\mathrm{ab}}$ & $0.437^{\mathrm{d}}$ & $0.570^{\mathrm{c}}$ & $0.414^{d}$ & $0.541^{\mathrm{cd}}$ & $0.430^{\mathrm{d}}$ & $0.524^{\mathrm{c}}$ \\
\hline 3 & $0.753^{a b}$ & $0.818^{\mathrm{a}}$ & $0.417^{\mathrm{cd}}$ & $0.270^{\mathrm{e}}$ & $0.446^{\mathrm{d}}$ & $0.413^{\mathrm{d}}$ & $0.528^{c}$ \\
\hline 4 & $0.753^{a b}$ & $0.602^{b c}$ & $0.728^{a b}$ & $0.528^{\mathrm{cd}}$ & - & - & $0.652^{\mathrm{a}}$ \\
\hline 5 & $0.753^{a b}$ & $0.677^{\mathrm{b}}$ & $0.595^{b c}$ & $0.456^{\mathrm{d}}$ & $0.406^{\mathrm{d}}$ & - & $0.577^{b}$ \\
\hline 6 & $0.753^{a b}$ & $0.751^{\mathrm{ab}}$ & $0.694^{b}$ & $0.435^{\mathrm{d}}$ & $0.401^{\mathrm{d}}$ & - & $0.606^{\mathrm{ab}}$ \\
\hline 7 & $0.753^{\mathrm{ab}}$ & $0.512^{\mathrm{cd}}$ & $0.661^{b c}$ & $0.469^{\mathrm{cd}}$ & $0.409^{\mathrm{d}}$ & - & $0.560^{b c}$ \\
\hline 8 & $0.753^{a b}$ & $0.570^{c}$ & $0.417^{\mathrm{d}}$ & - & - & - & $0.580^{b}$ \\
\hline \multirow[t]{4}{*}{ Average } & $0.753^{\mathrm{a}}$ & $0.607^{\mathrm{ab}}$ & $0.594^{b}$ & $0.429^{\mathrm{c}}$ & $0.466^{\mathrm{bc}}$ & $0.404^{\mathrm{c}}$ & \\
\hline & & \multicolumn{2}{|c|}{ L.S.D ${ }_{0.05}$} & B & & & \\
\hline & & \multicolumn{2}{|c|}{ Season 1} & 0.0 & & & \\
\hline & & \multicolumn{2}{|c|}{ Season 2} & 0.0 & & & \\
\hline
\end{tabular}

Table 6. Effect of 1-MCP and ethylene treatments and storage temperature on total sugars content of banana fruits during 2007 and 2008 seasons

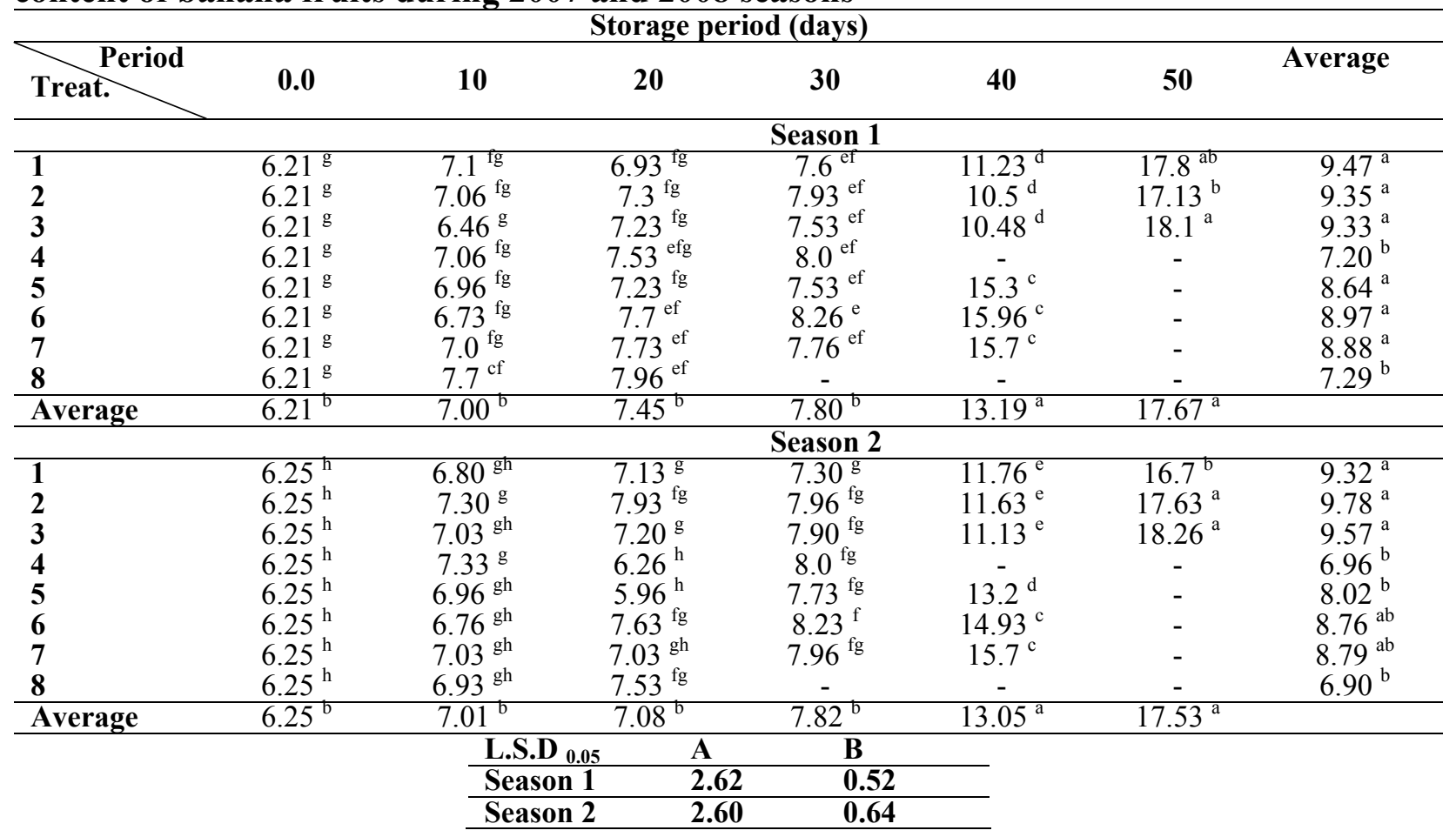


Table 7. Effect of 1-MCP and ethylene treatments and storage temperature on reducing sugars of banana fruits during 2007 and 2008 seasons

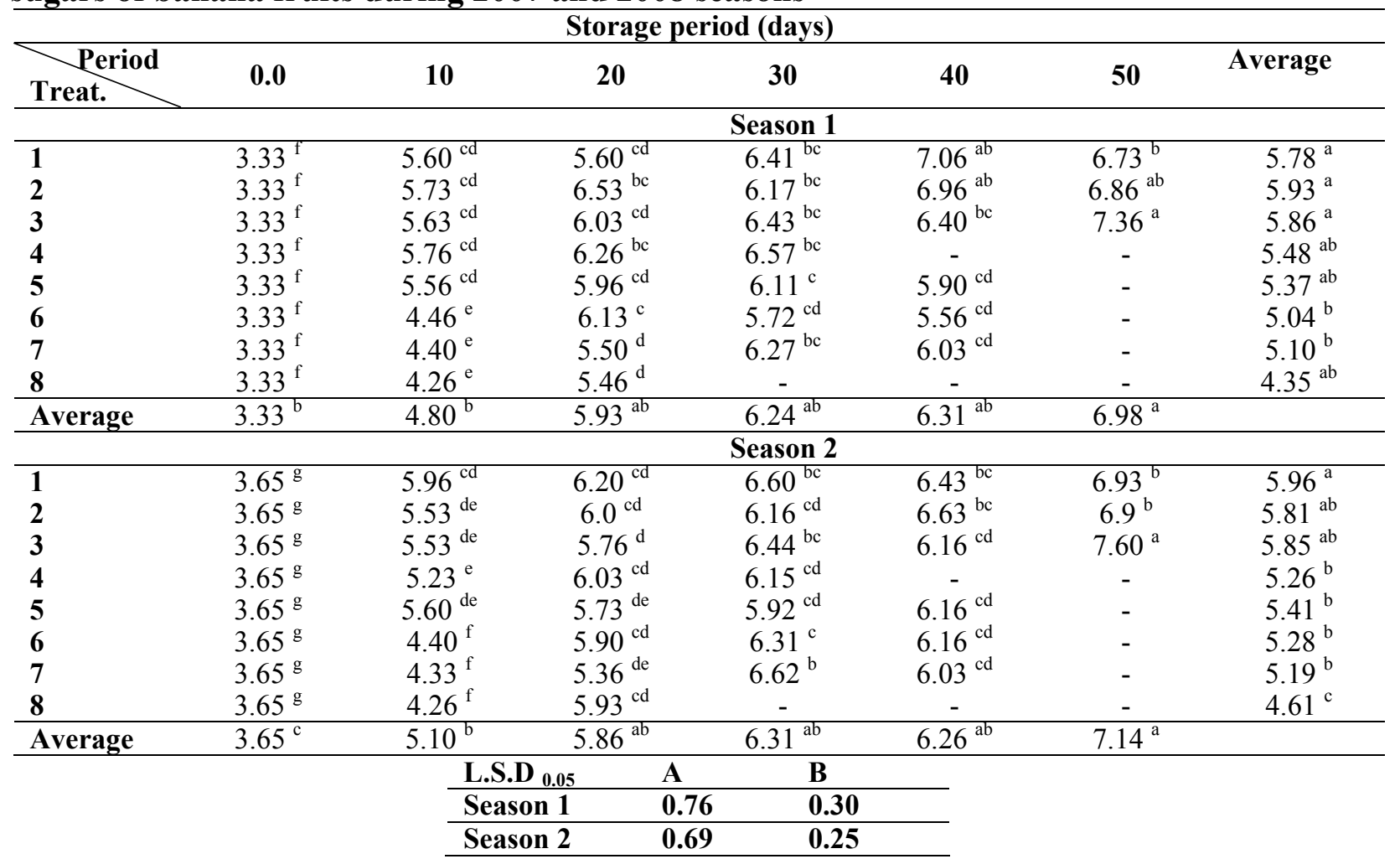

Table 8. Effect of 1-MCP and ethylene treatments and storage temperature on non reducing sugars of banana fruits during 2007 and 2008 seasons

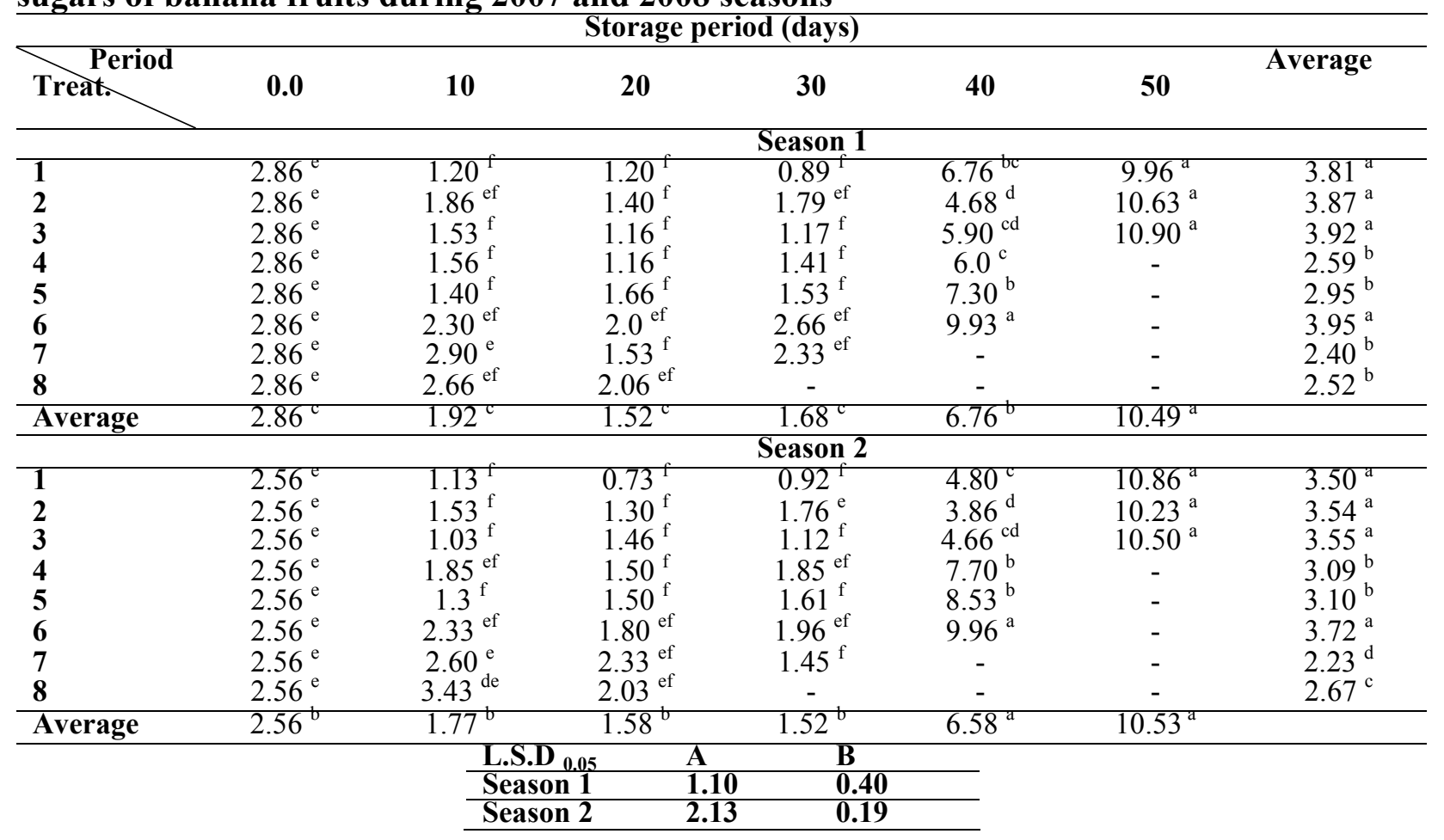


Table 9. Effect of 1-MCP and ethylene treatments and storage temperature on Color Index of banana fruits in 2007 and 2008 seasons

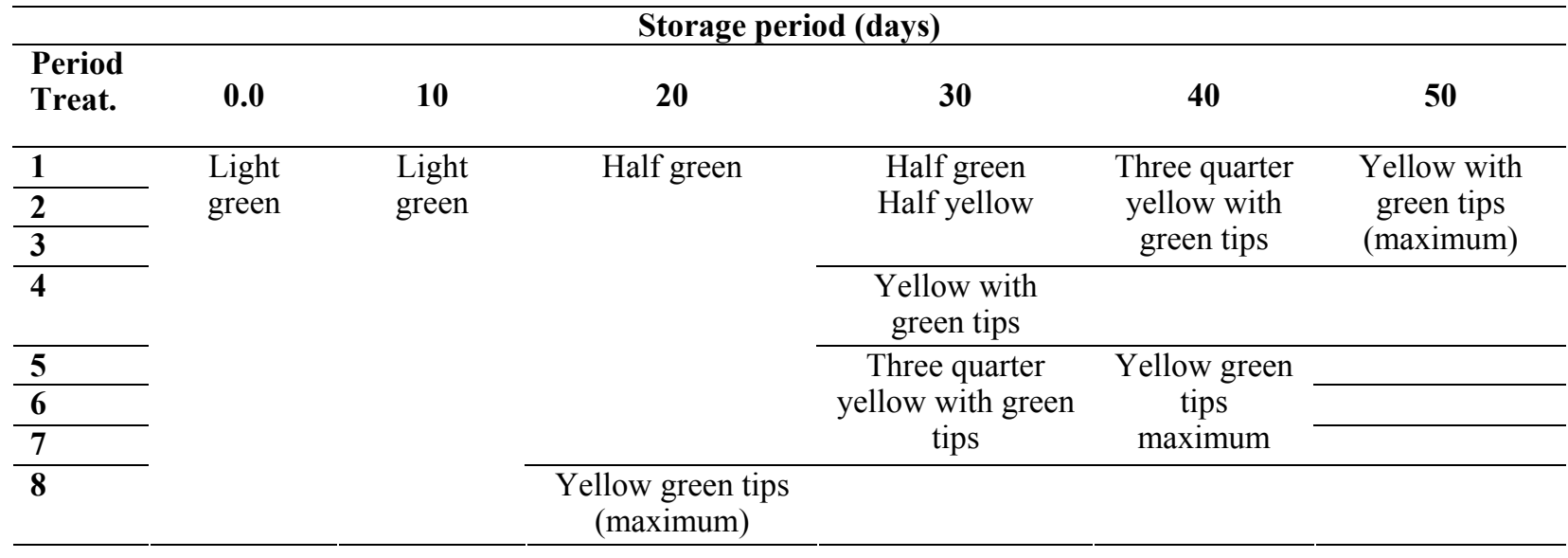

The green fruits changed to the yellowish green after 40 days of storage.Fruits treated with $\mathrm{MCP}(0.01,0.5,1$ $\mathrm{ppm})$ and stored at $13^{\circ} \mathrm{C}$ their changed color to yellow with green tips (maximum) in 50 days of storage and control fruits $\left(\mathrm{T}_{4}\right)$ changed color to yellow with green tips in 30 days of storage and control fruits $\left(\mathrm{T}_{8}\right)$ changed color in 20 days of storage (Boonyaritthon and Kanlayanarat, 2009) on banana fruits "Klaui Kai" and Basel et al. (2002), Clara Pelaya et al. (2003) and Rippon and Trochoulias (2007) found similar results.

\section{REFERENCES}

Argenta, L.C. and M. Mondardo, 1994. Maturity at harvest and quality after storage of Gala apples. Revista Brasileira de Fisiologia Vegetal. 6 (2):135-140.

Association of Official Agriculture Chemists (A.O.A.C), 1990. Official Methods of Analysis $13^{\text {th }}$ Ed, Washington. D.C., USA.

Basel R.M., K.Racicot. and A.G. Senecal, 2002. Long shelf life banana storage using MAP storage coupled with postharvest MCP treatment. Fruit and vegetable product fresh fruits and vegetables 6-18.

Boonyaritthon gchai P., Kanlayanarats, 2009. Effect of 1MCP treatment on the postharvest quality of banana fruits "Kulai Kai" Proceeding of the VIth International Postharvest Conference. Turkey, April, 12.

Calvo, G. 2002. Effect of 1- methylcyclo propene (1-MCP) on pear maturity and quality.

www.inta.gov.or/altovalle/actividad/investingacion/poscos echa/pdf/calvo-1-MCP-pera.

Chen, P.M. and W. M. Mellenthin, 1981. Effects of harvest date on ripening capacity and postharvest life of d'Anjou pears. J. Amer. Soc. Hort .Sci 106(1): 38-42.

Clara Pelaya, Eduardo V.de B-Vilas-Boas, Mohamed Benichou and Adel A. Kader (2003). Variability in responses of partially ripe bananas to 1- methylcyclo propene postharvest. Biology and Technology 28-75.
David B. Whyte, 2009. 1-MCP on banana. Food Science, 1216.

Dnake, S.R. 1998. Maturity and storage of "Cameo" apples. Tree Fruit Postharvest Journal. 9 (2):16-19.

Domingo Martiner- Romero, Eve Dupille, Fabian Guillen, Juan M. Valverde, Maria Serrano, and Daniel Valero. 2003. 1-MCP increases storability and shelf life in climacteric and Nonclimacteric plums J. Agric. Food Chem. 51(16) pp, 4680-4686.

Golding, J.B., D.Shearer, S.G. Wyllie and W.B. McGlasson. 1998. Application of 1-MCP and propylene to identify ethylene dependent ripening processes in mature banana fruit. Postharvest Biol. Technol. 14, 87.

Gomez, K.A. and A.A. Gomez, 1983. Statistical procedures for agriculture research. $2^{\text {nd }}$ ed. John Wiley and Sons, New York.

Jiang, W., M. Zhang, J.He and L. Zhou, 2011. Regulation of $1-\mathrm{MCP}$ treated banana fruits quality by exogenous ethylene and temperature. Sage Journal online, 17(3).

Joyce, D.C., A.J. Macnish, P.J. Hofman, D.H. Simons and M.S. Reid. 1999. Use of 1- methylcyclo propene to modulate banana ripening. In: Kanellis, A.K.(Ed.), Biology and Biotechnology of Plant Hormone ethylene 189/ 190.

Loomis, W.E. and C.A. Schull. 1937. Methods in Plant Physiology McGraw-Hill. Publishing company Inc. New Delhi, India.

Lopez, A.C., A.C. Hernandez, F.G. Lara and O.P. Lopez, 2003. Physio-chemical changes during ripening in storage of two varieties of prickly pear stored at $18^{\circ} \mathrm{C}$. J. Food Technol., 40(5): 461-464.

Macnish, A.J., Joce, DC., Hofman, P.J., Simons, D.H., Reid, M.S. 2000. 1 methylcyclo propene treatment efficacy in preventing ethylene perception in banana fruits and grevillea and wax flowers. Aust. J. Exp. Agric. 40,471.

Malik, C.P. and M.B. Singh. 1980. Plant Enzymology and Histo-Enzymology- A text Manual, PP. 276- 277, Kalyani Publishers, New Delhi, India. 
Yassin M.Naglaa and Tayel, A. Enas. 2010. The use of film wrapping, hot water and wax in improving postharvest quality of cactus pear fruits. Alexandria Journal of Agriculture Research, Vol. (55), No. (1): 51-58.

Narayana, C.K., M.M. Mustafa and S. Sathiamoorthy. 2006. Effect of packaging and storage on shelf life and quality of banana CV. Kar puravalli. Indian journal of Horticulture (India). Vol. (59) (2) p. 113-117.

Ramma, SP., Beni Madhu and P.Pearthum. 1998. Postharvest quality improvement of banana.

www.gov.mv/portal/sites/ncb/moa/forc/mas99/553.htm

Rippon, LE. and T. Trochoulias. 2007. Ripening responses of bananas to temperature. Australian Journal of Experimental Agriculture 16 (78): 140-144.
Salvador, A., J. Cuquerella, J.M. Martinez-Javege. 2003. 1MCP treatment prolongs postharvest life of "Santa Rosa" plums. Journal of Food Science. 68: 1504-1510.

Silva, S.M., M.F Lopes, D.M. Brito Primo and L.B.V. Torres, 2009. Pulp color changes during storage of cactus pear fruit coated with yam starch. Acta Hort. (ISHS), 811.

Sisler, E.C. and M. Serek. 1997. Inhibitors of ethylene responses in plants at the receptor level. Recent Developments. Physiol. Plant 100, 577, 582.

Yueming, J., D.C. Joyce and A.J. Macnish. 1999. Responses of banana fruits to treatment with 1- methylcyclo propene. Plant growth Regul. 28, 77, 82.

Ziosi, V., A. Bergoli, G. Fiori, M. Noferini and G. Costa, 2007. 1-MCP effects on ethylene emission and fruits quality traits of peaches and nectarines. Advances in Plant Ethylene Research, 4: 167-174. 


\section{पad}

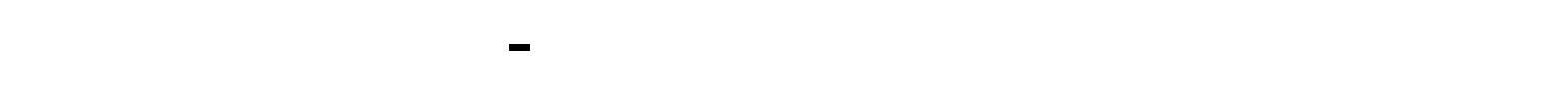

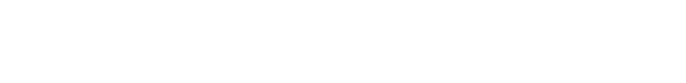

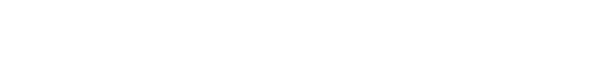

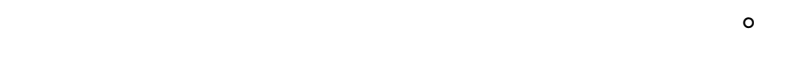

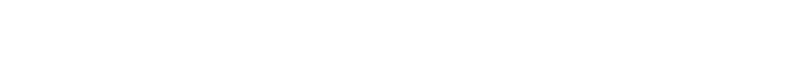

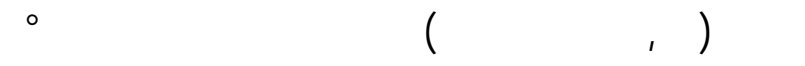

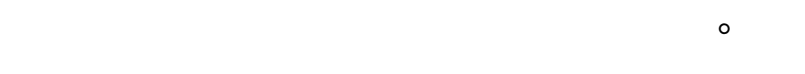

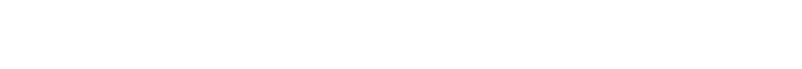

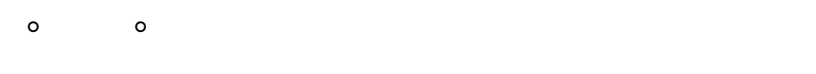

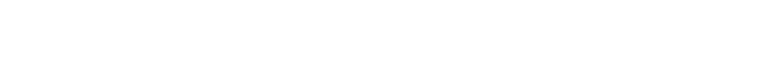

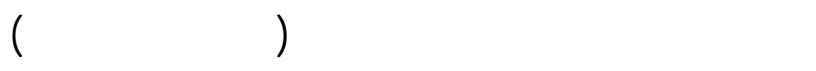

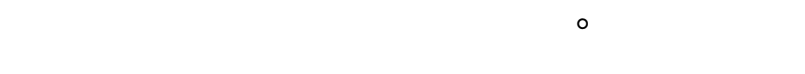

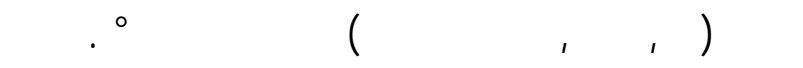

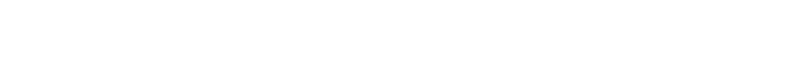

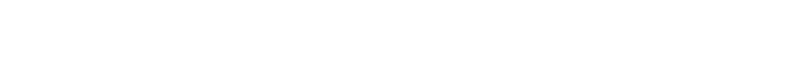

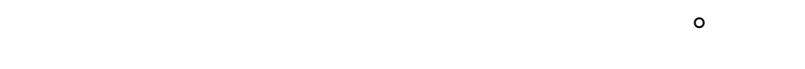

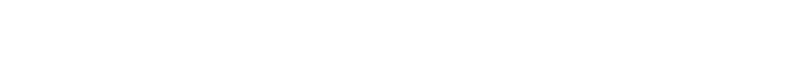

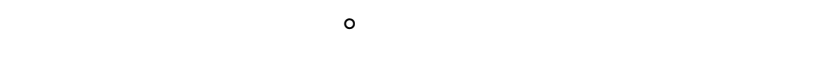

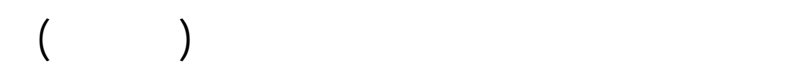

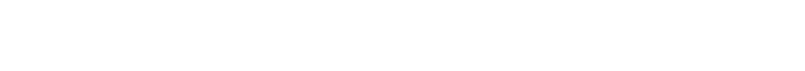
كما وجد أه كلما ققدت فرتات التخرنن لُ صلابة الثم ار

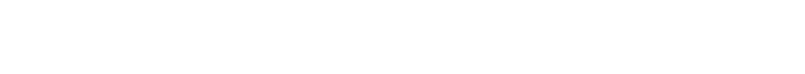

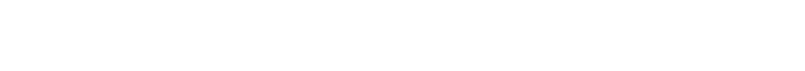
والخزتة وكذلك تهذ اللون إزدادت مع ناية فترات التخزينسواء

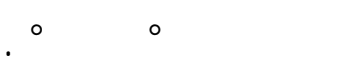

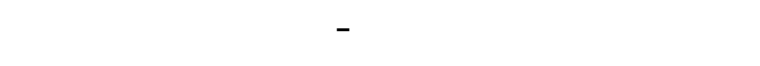

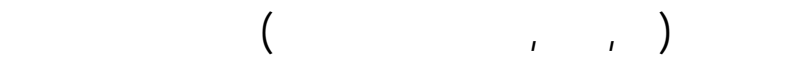

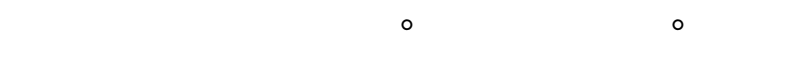

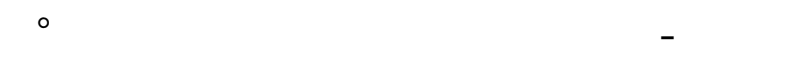

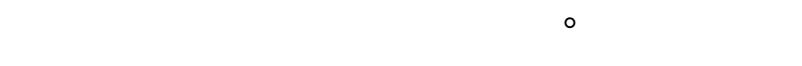
والسكريت الكلية ونسة آلواد الصلة الكلة للثمار.

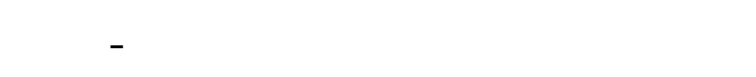

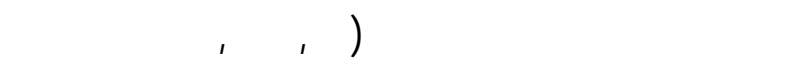

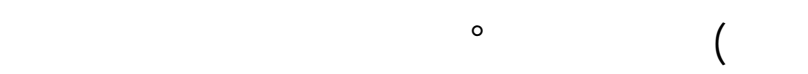

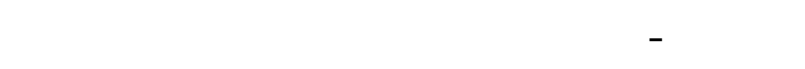

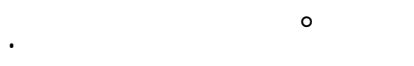

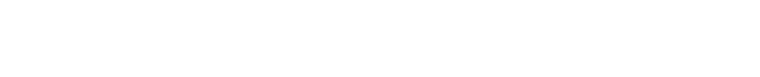

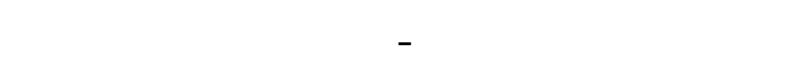

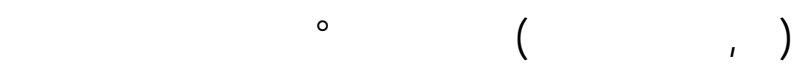

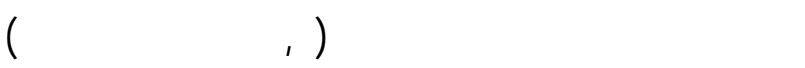

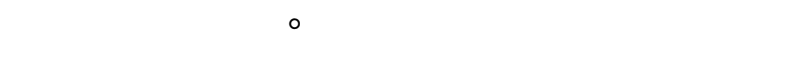

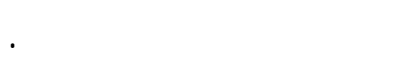

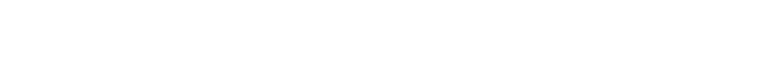

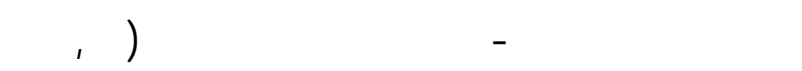

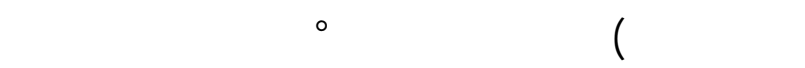
. وكل هنأك تأتم جوهرى علي على السكريت الكلية بالثم ار

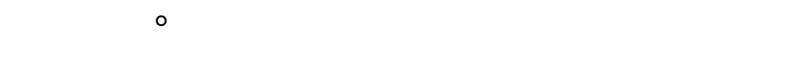

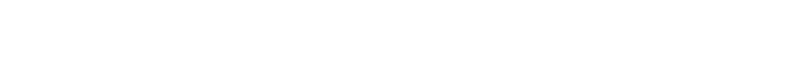

